\title{
A Gender Perspective of Translation: Taking Three Chinese Versions of The Purple Color as an Example
}

\author{
Lihua Yang \\ School of Foreign Studies, Yangtze University, Jingzhou, China
}

\begin{abstract}
The Color Purple is one of the best-selling novels in the west, which is very popular among people of different colors, different levels and different countries. Many Chinese translators have tried to translate it into Chinese. Because it is a typical feminist novel, so it is very meaningful to compare its translations and to analyze the gender awareness of translators in the translation process. This paper selected the versions of Yang Renjing (male), Tao Jie (female) and Lu Shujiang (female) to make a comparative study. The three translations have different stylistic characteristics. The main difference lies in their comprehension and expression of some words and phrases featured feminism. Male and female translators reflect significant gender differences.
\end{abstract}

Index Terms - feminism, gender differences, translations of The Color Purple

\section{INTRODUCTION}

Everyone will be shocked by the prosperous translation history if we take a look at the translation's development. As recorded, the history of translation can be traced back to the third century B.C. when seventy Judaic scholars translated The Old Testament in Alexander city in ancient Egypt. For a long time, traditional translation studies have tended to consider the source text as the "absolute standard" in the judgment and evaluation of a translation work. As a result, translators should try their best to reduce their subjective involvement and "reproduce in the receptor language the closest natural equivalent of the source-language message, first in terms of meaning and second in terms of style" (Nida, 1982, p. 55).

When Simone de Beauvoir (1949) wrote "one is not born, but rather becomes a woman", she was talking about gender. But it was in the 1970s did western translation study take its cultural turn and translation studies be recognized to be a separate discipline in the 1980s. Since translation was sexualized in ancient times, it provided a metaphorical framework for translation studies. Feminism has long been influenced by deconstructionism, post-colonialism, cultural studies, etc and since the 1980s, has taken effects in translation theory. The feminist thoughts, which originated from the two waves of women's movement in 19th century and 20th century, have influenced many fields, including translation. Since then, gender theory and feminist literature criticism have influence on translation studies. And different feminism schools have emerged and been developing at a surprising speed. Some scholars have noticed that feminism also have given great impact on the field of language studies and literature studies.

\section{THE COLOR PURPLE AND ITS WRITER}

\section{A. About Alice Walker}

Alice Walker, one of the most distinguished black woman writers in American today, was born in 1944, in a black family located Georgia Southern Ethan Dayton. At that time, Alice Walker attended college through her mother's income by working as a maid even though black children were not supported to be educated. She deeply appreciates the difficulties and hardships of being black. And at the age of eight years old, her eye was accidentally shot by his brother when they were playing a game named "cowboys and Indians". Because of not getting immediate treatment, she became blind, and because of the scar on her face she became shy. From then on, she began to write poetry, which was an outlet to release her own feelings. When she was fourteen years old, fortunately, the scar was removed. And later she became high school prom queen and class valedictorian. She began to learn to see the nature of things and people from this miserable experience. The Color Purple created in 1982 is her most successful one. Immediately upon publication of the novel caused widespread concern the U.S. critics. Critic Peter Scott had called it "an American novel of permanent importance. In 1984 she was awarded the Literature Pulitzer Prize, the highest award in American, and the National Book Award. The book continues to get reprinted, sold nationwide in the latter years.

\section{B. The Background of The Color Purple}

The Color Purple is an excellent literary work of black feminism. Alice Walker in this novel, from the perspective of the black feminist literary creation, fully describes and shows the black women by gender and racial oppression and 
living conditions. The heroine, Celie, was awakened from the numbness to independence, to autonomy and to the equal status with men in life. Fighting experience as the main trail, it highlights the dual oppression of black women and the desire to live and chase perfection. To express this theme, Alice Walker used a lot of symbolic image which is full of feminine meaning, so that the entire novel is full of marvelous colors and thought-provoking philosophy highlights of black feminist thoughts and ideas. Many comments had praised the novel The Color Purple. Smith says (1995) "The book is like a jewel. Any way you hold it to the light you will always see something new reflected" (p.232).

\section{Gender Differences in the Translation of The Color PurPle}

\section{A. The Feminism in the Translations of The Color Purple}

As Simon said (1996), "translation has at times emerged as a strong form of expression for women-allowing them to enter the world of letters"(p.39). Feminist translation theory aims to distinguish and make comments on the tangle of concepts which concerns both women and translation to the bottom of the society and the literary ladder. Feminist translation theory has introduced the gender perspective into translation studies. For feminist translation, "fidelity is to be directed toward neither the author nor the reader, but toward the writing project - a project in which both writer and translator participate" (Simon, 1996, p.2). The influence of gender identification on translation has been under investigation. In translating gendered texts, the translator may present a gender perspective which is different from his/ her own. Feminist translators "have tried out new words, new spellings, new grammatical constructions, new images and metaphors in an attempt to get beyond the conventions of patriarchal language that, in their view, determine to a large extent what women can think and write" (Flotow, 1997, p.15).

In some cases, female translators also add their own ideas which more strongly highlight the intent of the original. Feminist translators see "a parallel between the status of translation, which is often considered to be derivative and inferior to original writing, and that of women, so often repressed in society and literature" (Munday, 2001, p.131). When Celie decided to leave and shouted out,

“I'm poor, I'm black, I may be ugly and can't cook, a voice say to everything listening. But I'm here." (Walker, 1982, p.17)

In translation, Lu Shujiang profoundly realized that the voice of Celie is so strong: she is no longer the girl that was abused by his stepfather Mr-.; she has her own thought. Therefore, she translated these words:

“我是贱, 我是黑, 也许连饭也做不好, 我听见一个声音在对所有倾听着的万物说。可是, 我就站在这儿, 谁也 不能看不见我。谁也不能。”( $\mathrm{Lu}, 1986, \mathrm{p} .13)$

In the end of the sentence was added “谁也不能看不见我。谁也不能”, which shows Celie's determination of winning independence and others' respect by repeating what she said. This creation shows the gender awareness of the translator.

Furthermore, Tao Jie made it clear that she translated The Color Purple because it related to gender translation. She said: At that time my American friend send me this book, I'm very moved by it, I think of my mother and other women in that generation. I think the Chinese women out of the home in the fifties and sixties, becoming economic independence is one of the major achievements of women's movement, and the degree of Chinese women's liberation was higher than elsewhere, especially than the United States. She proposed to translate the book, mainly because the heroine is getting more and more confident after having her own career. This indicates that from the beginning of the selection, female translator is influenced by gender awareness.

Translation is not just a simple one-to-one transfer between two languages, it is known that:

"Every translation is directed at an intended audience, since translation means to produce a text in a target setting for a target purpose and target addressees in target circumstance" (Nord, 2004, p.12).

The female translator Tao Jie was born in 1936 and she graduated from western language and literature department in Beijing University. In the year 1986 her version of The Color Purple was first published out by Foreign Literature Press in Beijing. As for the choice of the literary work The Color Purple, Tao Jie admitted that it derived from her own sympathy for Walker's description of the black women's low social status and suffering from oppression under the patriarchal dominance, which Tao Jie thought are similar to Chinese women's situation that need people's attention and activity to change the situation.

Therefore, from the above analysis, we can draw definite conclusions that female translator is indeed subject to the influence of gender and this effect which sequence from the translator and the translation between the lines and the initial selection of translation can be manifested. Just as Sherry Simon held that,

"My translation practice is a political activity aimed at making language speaks for women. So my signature on a translation means: this translation has used every translation strategy to make the feminine visible in language" (Simon, 1996, p.15).

\section{B. Gender Differences in Women'S Social Status}

Through comprehensive and detailed comparison of translations, I found female translator in the preface and translation reproduces more prominent feminist ideology of the original text, showing more intense gender awareness. In a word, Lu Shujiang and Tao Jie put more emphasis on the novels for women issues, and also more clearly highlights 
the feminism thought of the novel. While Yang Renjing also mentioned the novel's feminist intention, but he paid more attention to social issues, not the women's social status.

Although men and women can be translators of the original, dealing with feminist plot and some gender-related details, female translator, under the impact by the gender awareness, can more accurately grasp and reproduce the original, even prominent. Whereas male translator because of the lack of gender awareness, not only did not notice these details of original feminism expression, but also weaken or even distort the original feminist intent. Such as,

1.a. The original version:

The original: She has the nerve to put one hand on her naked hip and bat her eyes at me. (Walker, 1982, p.17)

1.b. Tao Jie's version:

她居然敢把一只手放在光屁股上对我飞个媚眼。(Tao, 1986, p.10)

1.c. Lu Shujiang's version:

她满不在乎地把手搭在她那光光的屁股上冲我眨了眨眼。( $\mathrm{Lu}, 1986, \mathrm{p} .13)$

1.d. Yang Renjing's version:

她厚着脸皮把一只手放在光屁股上，还对我挤眉弄眼。(Yang, 1987, p.12)

This scene took place when Celie helped ailing Shug bathing. Celie feared men, but when she saw Shug's body, she felt the need of self, which made she cannot help staring at her. Shug was aware of it, but did not care, even boldly show herself. She in the sentence refers Shug. Tao Jie and Lu Shujiang have insight into Celie's surprise and envy to the body style of Shug, and thus chose these neutral words, such as “居然敢”, “对我飞个媚眼”, “满不在乎”, and “冲我眨 了眨眼”, to express Celie's surprised tone. In the treatment of her eyes on dissolute Shug, Yang Renjing not only did not realize Shug beyond ordinary women's self-consciousness, but also not realize that at this time Shug shocked Celie's heart. How fade Celie's true feelings is! She was changed into his own moral judgment officer: Shug dared to pose bare ass and blink to me, what a shame ah! Therefore, the translator chose “厚着脸皮” and “对我挤眉弄眼”, two derogative and hostile phrases, that shows his own distaste for Shug.

From analysis and comparison of the three examples, we can find that in the translation of the sentence about the women's social status, male translators and female translators shows the differences. Female translators are more sensitive to the words of description of women in the novel, and they choose the words to uplift women's social status, or they call on other women to fight for their own social status uplifting. But male translators are unaware of it, and they just choose the words in their willing.

\section{Gender Differences in Sex Description}

The sex description in The Color Purple is an important part in the source text. Celie's discovery of sexy features of being a woman and sexual desire showed the process of her growth to an independent woman who should be equal with man. And she gradually realized that sexual desire was a normal human desire instead of some scoundrel thing. So the sex description is very important in expressing feminism in the novel. Such as,

2.a. The original:

Listen, she say, right down there in your pussy is a little button that gits real hot when you do you know what with somebody. It git hotter and hotter and then it melt. That the good part. But other part good too, she say. Lot of sucking go on, here and there, she say. Lot of finger and tongue work. (Walker, 1982, p.69)

2.b. Tao Jie's version:

听着，她说，你下身有个圆东西。你干那种事的时候，这个圆东西会发热。它越来越热，热的化掉了。这是 最好的地方。别的地方也好极了, 她说。这儿那儿, 吮啊吸啊的, 她说。手指头, 舌头都忙个不停。(Tao, 1986, p.55)

2.c. Yang Renjing's version:

听着，她说，在你的下身的正下方有个小小......, 你跟男人相好时， 然后自己渐渐消失。这是 个好部位，但别的部位也不错，她说，全身都可以 (Yang 1987 . p. 77 )

Celie told Shug that Mr.- did not care about her feeling but just regarded her as a vent tool. Shug was so surprised to know that to be a married woman and a mother for two children, Celie could not find any pleasure in her sex with Mr.and even did not like it. And what's more, Celie did not know anything about her body. Shug led Celie to know about her own body, to find the physiological features of her body as a married woman. She introduced female physical organ to Celie, helped her to know her body, and introduced her to enjoy her sex.

The first step for woman to get confidence and self-confirmation is to recognize and validate her body. And Tao Jie realized this point and translated all the sentences about physiological feature of female genital. She translated the feeling of sex vividly, conveying the author's intention to help the women under the oppression of man to get confidence and self-confirmation and find the significance and value of being a woman, and to enjoy their lives. It is a course of self-confirmation, the first step to get independence, indignity and equality in the patriarchal society. Yang Renjing may think the sexual description sentences too offensive according to Chinese implicit culture, and he did not translate the sentences out. But he did not realize that this was an important part for women to get confidence and self-confirmation. 
From analysis and comparison of the translation from three examples above, it shows that female and male translators have different attitudes towards sentences concerning sex and female translator was much careful in choosing the words to manifest heroine's feeling in sex, calling on them to get free from body and soul constriction.

\section{Gender Differences in Appearance and Action}

The main characters in the novel are women, so appearance and action description is an important part in the novel. Through the analysis of the translation of the appearance description in the original, we found that different translators in different genders show different attitudes towards women's appearance and beauty in translation.

3.a. The original:

And she dress to kill. She got on a red wool dress and chestful of black beads. A shinny black hat with what look like chick in hawk feathers curve down side one cheek. (Walker, 1982, p.41)

3.b. Tao Jie's version:

她打扮得讲究极了。她穿着一件红色的羊毛裙, 胸前挂着好些黑珠子。一顶耀眼的黑帽子上插了几根好像是 鹰身上的羽毛, 羽毛弯下来贴在面项上。（Tao, 1986, p.33）

3.c. Yang Renjing's version:

她穿的过分讲究。她穿了一件红色毛线衣, 胸口挂了黑珠子, 戴了闪亮的黑帽子, 帽子上插着野鸡毛, 一半 弯到半边脸上。(Yang, 1987, p.46)

Shug was Mr.-'s mistress. Contrary to Celie, the heroine in the novel, Shug was a woman dared to love and to do the things that her heart desired to. She dressed herself very well, sang in bars to earn the money and liked showing herself off in the public. But she was scored and despised by the people in that patriarchal society. Knowing Shug's character, Celie adored and admired her. In her heart she was eager to get escaped from Mr.-'s dominance. When Shug got sick - it was said that she got some woman disease, and nobody was willing to take after her. But Mr.- took her home. It is the first time Celie saw Shug who she admired and wanted to be the people like her. The author used many words to describe Shug's appearance. And in Celie's eyes' she “dress to kill” (Walker, 1982, p.41) It shows her admiration to Shug. Tao Jie used “讲究极了” to show Celie“s envy and surprise to see that Shug dressed so beautiful. But Yang Renjing used the derogative term “过分”, which misunderstood the author's intention. And he translated the sentence in a man's angle, which shows his despise to Shug. Why the differences can be seen from their versions. We first take a look at the explaination of the words "red wool dress" in the Oxford Advanced Learner's English-Chinese Dictionary.

For the words "red wool dress", two meanings of the dress are "a piece of woman's clothing that is made in one piece and covers the body down to the legs, sometimes reaching to below the knees, or to the ankles" and "clothes for either men or women" (Hornby, 2004, p.520).

Yang Renjing chose the origin meaning “红毛线衣”, which is just like describing a common woman but not the woman who pursued beauty and was fond of dressing up delicately. And Tao Jie chose the characters “红色的羊毛裙” to show Shug's beauty and the female's self-affirmation to readers, and it also gives the readers the feeling that Shug cared about her appearance and desired to give good impression to others even if she was badly sick. Being a woman, Tao Jie paid attention to the beauty of the woman.

\section{CONCLUSION}

Since the "Cultural Turn" in the 1970s, translation study has broadened its research boundary under the influence of many intellectual theories, including feminism. As a political and literary activity, feminism has great influence on the theory and practice of translation. Western feminist translators begin to explore the metaphoric relationship between gender and translation. By doing so, they want to change the traditional concept that original (man) is superior to translation (woman), and to raise the status of translation (woman). For feminism project, feminist translators in the West have employed many radical and unconventional translation procedures like supplementing, prefacing and footnoting, and hijacking to highlight women translators' subjectivity and creativity. Feminist translators make their creative intervention in translations with the purpose to eliminate the gender discrimination and make the public aware of women's unequal treatments. In 2002, the Western feminist translation theory was introduced into China and then has undergone rapid development. However, most of its research remains on the theoretical level. We are expecting more researches on translation practice. Gender difference is the foundation of feminist translation theory, which holds that this difference takes effect throughout the whole process of translation, especially in translator's gender and genders in translation. The aim of advocating feminist translation is to make women visible and resident in society, to allow women's voices to be heard. In feminist translation, translation becomes an activity influenced by translator's identity, views of the world, living background and environment. Feminist translators emphasize the subjectivity from the perspective of the women by stressing independence and equality. The purpose of the feminist translators is to challenge the patriarchal language and to raise the status of female translators on the cultural intervention in the translating process. Feminist translation theory has enriched translation studies with new insights. This thesis, adopting comparative study of the feminist translation theory, makes a detailed comparative study of three Chinese versions of The Color Purple translated by Tao Jie, Lu Shujiang and Yang Renjing by exploring feminist consciousness and 
feminist translation studies applied in these versions. This thesis discloses feminist consciousness of translators, so that it can guide the application of feminist translation studies to practice.

Generally speaking, female translator promotes gender neutrality in language and makes use of auxiliary words and emotive words of mood to strengthen the female's features lively and vividly to challenge the patriarchal language and uplift women's social status, to get equal right with men. Study of the versions of the novel The Color Purple can be carried in other key feminine features in the novel. But the thesis is just a small part in the whole feminist translation study. It should be studied and figured out that the translators' feminist consciousness might be constricted or affected by some other internal factors.

\section{REFERENCES}

[1] Christiane, Nord. (2004). Translating is a Purposeful Activity. Shanghai: Foreign Language Education Press.

[2] Hornby, A. S. (2004). Oxford Advanced Learner's English-Chinese Dictionary. Oxford University Press.

[3] Lu Shujiang. (1986). The Color Purple: A Letter to God. Hefei: Anhu's Art Press.

[4] Luise, Von Flotow. (1997). Translation and Gender: Translating in the 'Era of Feminism'. Manchester: St. Jerome Publishing.

[5] Nida, Eugene A. (1982). Language, Culture, and Translation, Shanghai: Shanghai Foreign.

[6] Sherry, Simon. (1996). Gender in Translation: Culture Identity and the Politics of Translation. London: Routledge.

[7] Smith, Barbara. (1995). The Truth that Never Hurts: Black Lesbians in Ficiton in the 1980s. In Hoanne M Braxton \& Andree Nicola McLaughlin (eds.), Wild Women in the Whirlwind: Afro American Culture and the Contemporary Literary Renaissance New Brunswick: Rutgers University Press.

[8] Tao Jie. (1986). The Color Purple. Beijing: Foreign Language Press.

[9] Walker, Alice. (1982). The Color Purple, New York: Harcourt.

[10] Yang Renjing. (1987). Purple. Beijing: Beijing's October Art Press.



Lihua Yang was born in Fuzhou, China in 1982. She got her doctoral degree in 2012 at Foreign Studies College, Hunan Normal University (HNU), Changsha, China. Her major field is in translation studies. Her doctoral dissertation is "A Study of Lin Shu's Translation". She is currently a lecturer at School of Foreign Studies, Yangtze University. 